
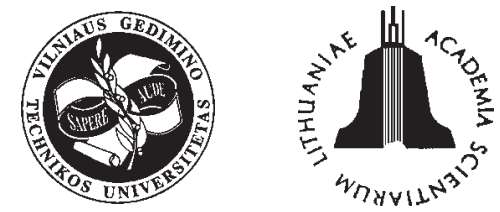

ISSN 1392-3730 print / ISSN 1822-3605 online

JOURNAL OF CIVIL ENGINEERING AND MANAGEMENT

http:/www.jcem.vgtu.lt

2006, Vol XII, No 1, 97-101

\title{
INVESTIGATION OF UNSTEADY HEAT TRANSFER PROCESS IN AN ONE-CELL BUILDING
}

\author{
Kęstutis Valančius ${ }^{1}$, Alfonsas Kazys Skrinska ${ }^{2}$, Sabina Paulauskaitė ${ }^{3}$ \\ Dept of Heating and Ventilation, Vilnius Gediminas Technical University, \\ Sauletekio al. 11, LT-10223 Vilnius, Lithuania \\ E-mail: 1'kestutis.valancius@ap.vtu.lt,.25krinska@ap.vtu.lt,. ${ }^{3}$ sabina.paulauskaite@ap.vtu.lt
}

Received 29 April 2005; accepted 21 Sept 2005

\begin{abstract}
All energy processes in buildings are usually unsteady, ie time dependent. But mostly the unsteady factors influence is not taken into consideration for energy demands, microclimate changes estimating. Therefore the practical observations and theoretical investigations show an undesirable behaviour of indoor thermal microclimate and energy use, even with modern enough control systems. As a result, new methods for problem solution and investigations develop. The paper presents some theoretical aspects of unsteady heat transfer analysis based on the energy conservation law. Additionally, an experimental research made at Solar energy investigation centre in Spain - Plataforma Solar de Almeria - results and its comparison with theoretical calculations are produced.
\end{abstract}

Keywords: energy conservation law, unsteady heat transfer, experimental investigation, building.

\section{Introduction}

Obviously heat transfer processes in buildings are always unsteady under real conditions. On the other hand, practical heat exchange calculations in buildings are based on steady-state process equations. Therefore practical observations and theoretical investigations show an undesirable behaviour of indoor thermal microclimate and energy use, even with modern enough control systems [1]. Even, usually at building operation period, unreasonably installed heat power is noticed. Unvalued heat inflows cause too high heating power and building overheating, and intermittent heating rises problem of too low installed power or long preheating time. The result of these reasons is a wrong buildings maintaining - the indoor climate does not satisfy the hygienic requirements.

Often energy savings are obtained at the expense of human health.

The known methods of unsteady heat transfer calculations in buildings are mostly not flexible and hardly applicable to engineering analysis [2-4]. The need for new ways of unsteady thermal processes in buildings still exists.

The solution of unsteady heat transfer problems can be reached on the basis of thermodynamics laws, specifically the conservation of energy for a control volume.

The subject of thermodynamics and heat transfer is highly complementary. The heat transfer may be viewed as an extension of thermodynamics, because it treats the rate at which heat is transferred. Conversely, for many heat transfer problems the first law of thermodynamics (the law of energy conservation) provides a useful, often essential, tool [5].

\section{Theoretical aspects}

Since the first law must be satisfied at every instant of time $t$, one option involves formulating the law on a rate basis. That is, at any instant, there must be a balance between all energy, as measured in joules per second. Alternatively, the first law must also be satisfied over any time interval $\Delta t$. For such an interval, there must be a balance between the amounts of all energy changes, measured in joules.

The general form of the energy conservation requirement may be expressed on a rate basis:

$$
\dot{E}_{\text {in }}+\dot{E}_{g}-\dot{E}_{\text {out }}=\frac{d E_{s t}}{d t} \equiv \dot{E}_{s t}
$$

The alternative form that applies to a time interval $\Delta \mathrm{t}$ is obtained by integrating equation (1) over time:

$$
E_{\text {in }}+E_{g}-E_{\text {out }}=\Delta E_{\text {st }} \text {. }
$$

If the inflow $E_{i n}$ and generation $E_{g}$ of energy exceed the outflow $E_{\text {out }}$, there will be an increase in the 
amount of energy stored (accumulated) $E_{s t}$ in the control volume etc. If the inflow and generation of energy equal the outflow, a steady-state condition must prevail, in which there will be no change in the amount of energy stored in the control volume [6].

The inflow $E_{\text {in }}$, the outflow $E_{\text {out }}$ are surface phenomena. The energy generation $E_{g}$ and energy storage $E_{s t}$ are volumetric phenomena.

The energy generation $E_{g}$ is negligible in building physics or it is straight expresses as thermal energy such as electric energy transform to thermal.

The method $[4,7]$ is based on calculating the evolution of the building temperature when it falls below its normal set-point. This evolution is calculated by a building model with three nodes representing the internal and external environments and the building structure. The internal thermal inertia of the building is represented by a capacitance whose temperature is the structure temperature. Heat exchanges between the structure and the external environment, between the structure and the internal environment and directly between the internal and external environments are taken separately into account.

Extending the thermal scheme [4, 7] and combining it with conservation of energy law for a control volume we can define the thermal energy balance scheme for a building (Fig 1).

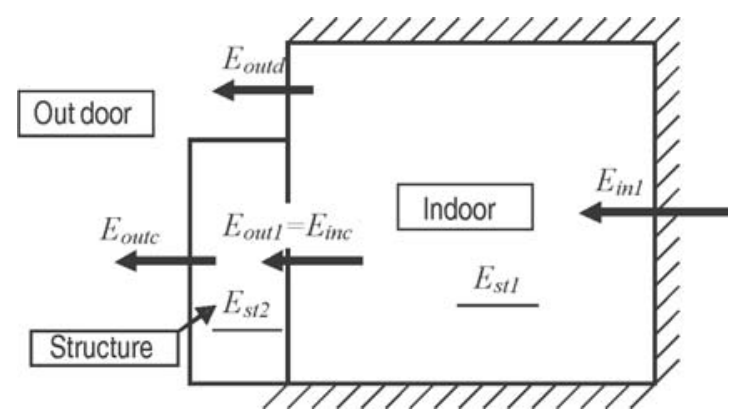

Fig 1. Thermal energy balance scheme for a building

This scheme consists of two thermodynamic systems with inflow-outflow and stored thermal energies.

Exploring Fig 1 expression of inflow energy to indoor air:

$$
E_{i n 1}=\Phi_{h} \cdot \Delta t
$$

Outflow energy from indoor air and inflow energy to structure:

$$
E_{\text {out } 1}=E_{\text {inc }}=H_{i c} \cdot\left(\theta_{i}-\theta_{c}\right) \cdot \Delta t .
$$

Outflow direct (through lightweight structures and infiltration) energy from indoor air to exterior:

$$
E_{\text {outd }}=H_{d} \cdot\left(\theta_{i}-\theta_{e}\right) \cdot \Delta t .
$$

Outflow energy from structure to exterior:

$$
E_{\text {outc }}=H_{c e} \cdot\left(\theta_{c}-\theta_{e}\right) \cdot \Delta t \text {. }
$$

Indoor air stored energy:

$$
E_{s t 1}=C_{1} \cdot\left(\theta_{i}-\theta_{e}\right) \text {. }
$$

Structure stored energy:

$$
E_{s t 2}=C_{2} \cdot\left(\theta_{c}-\theta_{e}\right) \text {. }
$$

Heat capacity of internal air $(\mathrm{J} / \mathrm{K})$ :

$$
C_{1}=V_{a} \cdot \rho_{a} \cdot c_{a} .
$$

Internal or effective heat capacity of the structure $(\mathrm{J} / \mathrm{K})[7,8]$ :

$$
C_{2}=\sum_{i=1}^{n} A_{i} \cdot d_{i} \cdot \rho_{i} \cdot c_{i} .
$$

Where $\Delta t$ - time step (s) and $\theta_{e}=$ const.; $d_{i}-$ effective thickness of the structure (heavy weight construction); $A_{i}, \rho_{i}, c_{i}$ - respectively, area, density and specific heat capacity of the structure.

Energy balance for both systems defining:

$$
\begin{gathered}
E_{\text {in } 1}-E_{\text {out } 1}-E_{\text {outd }}=\Delta E_{\text {st } 1}, \\
E_{\text {inc }}-E_{\text {outc }}=\Delta E_{\text {st } 2} .
\end{gathered}
$$

Change of stored energy $\Delta E_{s t 1}$ and $\Delta E_{s t 2}$ equals zero under steady-state conditions.

Basing on 11 and 12 Eqs, we can explore temperature change after time step $\Delta t$ for unsteady conditions:

Indoor air temperature after time step $\Delta t$ :

$$
\begin{aligned}
& \theta_{i}(\Delta t)=\frac{E_{s t 1}+\Delta E_{s t 1}}{C_{1}}+\theta_{e}= \\
& =\theta_{i}+\frac{\left[\Phi-H_{i c} \cdot\left(\theta_{i}-\theta_{c}\right)-H_{d} \cdot\left(\theta_{i}-\theta_{e}\right)\right] \cdot \Delta t}{C_{1}} .
\end{aligned}
$$

Structure temperature expression after the change of indoor temperature and the same time step $\Delta t$ :

$$
\begin{aligned}
& \theta_{c}(\Delta t)=\frac{E_{s t 2}+\Delta E_{s t 2}}{C_{2}}+\theta_{e}= \\
& =\theta_{c}+\frac{\left[H_{i c} \cdot\left(\theta_{i}-\theta_{c}\right)-H_{c e} \cdot\left(\theta_{c}-\theta_{e}\right)\right] \cdot \Delta t}{C_{2}} .
\end{aligned}
$$

Eqs 13, 14 allow to investigate exact temperatures change of unsteady process at any time.

Where $\theta_{e}, \theta_{c}, \theta_{i}$ - respectively, external air, structure and internal air temperatures $\left({ }^{\circ} \mathrm{C}\right) ; \Phi_{h}$ - heating power or other energy source (W); $H_{c e}, H_{i c}, H_{d}-$ respectively, heat loss coefficient $(\mathrm{W} / \mathrm{K})$ between the structure and the external environment, heat loss coefficient between the structure and the heated space and direct heat loss coefficient, which is $H_{d}=H_{w}+H_{v} \cdot H_{w}$ - sum of all heat loss coefficients of windows and doors, $H_{v}$ - the ventilation heat loss coefficient.

\section{Experimental investigation of unsteady heat trans- fer process in a one-cell building}

The experimental investigation was carried out at the Solar energy investigation centre Plataforma Solar De Almeria (PSA) in Spain. This project was made by the financial support of the "Improving Human Potential” programme of EU-DGXII. 
The aim of the experiment was to investigate unsteady heat transfer process in a one-cell building under natural conditions. Preparation and the main part of the experiment were carried out during a stay in PSA over a month.

The paper presents methods and results of the experimental investigation of one-dimensional unsteady heat process in one-cell building under the impact of solar radiation on one surface and unequal boundary conditions.

The obtained experimental data may be put into practice and help developing an unstable heat transfer theory in the multilayers using various methods of analysis.

\subsection{Equipment and investigation methods}

The LECE (Laboratorio de ensayos Energéticos para Componentes de Edificación) on the south side of the PSA forms a part of the European PASLINK network of laboratories for energy testing of buildings components. It consists of 4 test cells with a complete instrumentation for testing the thermal performance of building conventional and passive components under real outdoor conditions (Fig 2).

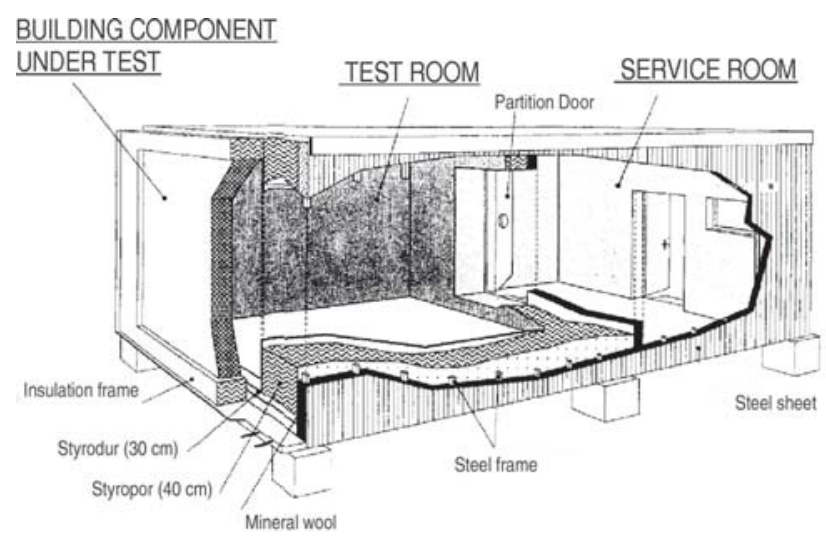

Fig 2. The scheme of the test room and the solar component under the test

The main tasks of the Laboratory:

- Accreditation for energy certification of building components, implementation of a quality system.

- Experimental testing of natural cooling techniques using vegetation, evaporative roofs and ventilation.

- Test and thermal characterisation of vertical and horizontal building components in collaboration with construction products manufacturers; active solar components, testing and thermal characterisation.

- Testing methodologies for thermal characterisation in component development and improvement.

A test cell of approximately the same size as a standard room was used in the experiment. The opposite wall to the service room is interchangeable with the test specimen $[9,10]$. A test component was the multilayer wall (Fig 3) of three different layers, ie $2 \mathrm{~cm}$ of plaster from

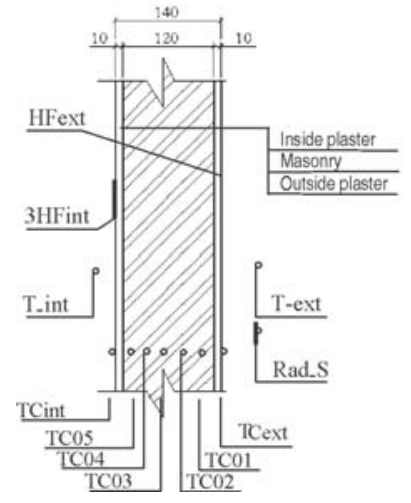
T-ext - internal thermometer;
TCext - thermocouple on outside surface;
TCO1 - thermocouple $3 \mathrm{~cm}$. from outside surface;
TCO2 - thermocouple $5 \mathrm{~cm}$, from outside surface;
TCO3 - thermocouple $7 \mathrm{~cm}$. from outside surface:
TCO4 - thermocouple $9 \mathrm{~cm}$, from outside surface:
TC05 - thermocouple $11 \mathrm{~cm}$. from outside surface;
TCint - thermocouple on inside surface: T-int - internal thermometer;
HFint -3 heat flux meters on inside surface; HFext - heat flux meter on outside surface; Rad -S - pironometer (for solar radiation).

Fig 3. Test component section with the installed measuring equipment

the outside, $12 \mathrm{~cm}$ of brick wall and $2 \mathrm{~cm}$ of plaster from the inside.

Thermocouples were installed in separate layers of the wall. Two thermoresistant thermometers were installed to meter the inside and outside air temperature. A pyronometer was installed on the outside surface to meter the total solar radiation. Heat flux meters were installed for investigating the heat flow -1 on the outside surface and 3 on the inside surface.

All equipment was connected to a computer. The computer was fixing the test data every 10 minutes.

Orientation of the test's component was to the south; the experiment was carried out in May, 2003.

\subsection{Results of the investigation}

Experimental data including the inside and outside air temperatures, temperatures of different layers of the testing wall, solar radiation and heat flow densities through the boundary densities was being got for a period longer than a month. The characteristic data of temperature distribution for 3 days are presented (Fig 4).

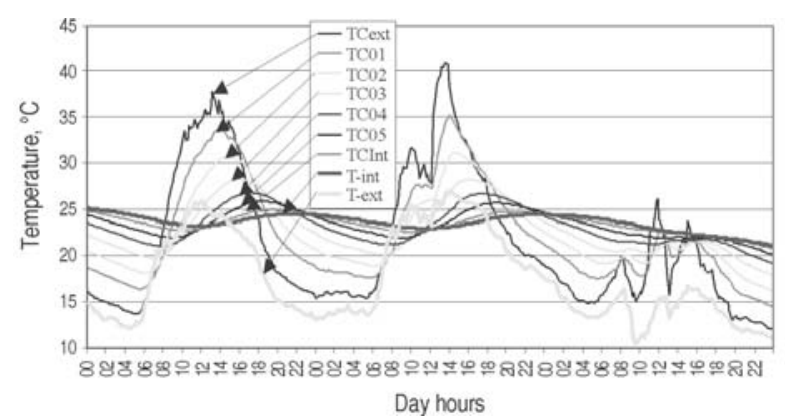

Fig 4. Temperature distribution

The outside air temperature maximum $-27-28^{\circ} \mathrm{C}$ appears near $1 \mathrm{o}^{\prime}$ clock PM (at midday), and minimum $13-14{ }^{\circ} \mathrm{C}$ at $2-4$ o'clock AM (at night). The third day sticks out because of temperature fluctuation at the bright period of day. The external surface temperature change is parallel to the outside air change. 
On sunny days ( $1^{\text {st }}$ and $2^{\text {nd }}$ day) temperature curves even move from the external surface to the internal one. "Temperature wave" - temperature curves moving - time from external surface to internal is about $7 \mathrm{~h}$, and from outside air to inside air - near $10 \mathrm{~h}$.

Heat flow densities analysis (Fig 5) shows the direct heat flow through the testing wall and the dependence on the total solar radiation.

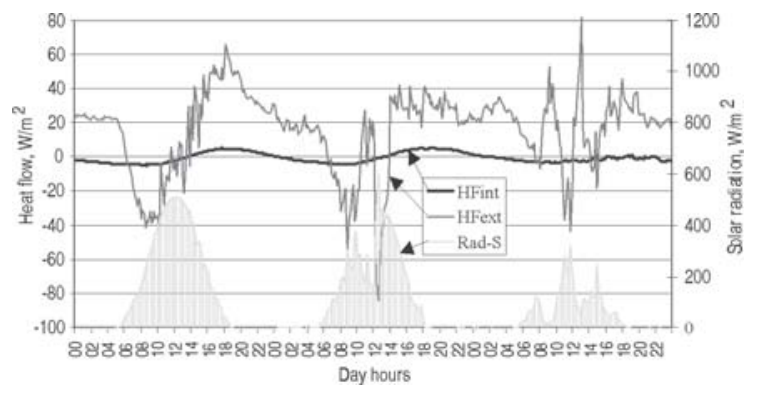

Fig 5. Heat flow densities and solar radiation

Here, "Rad-S" is solar radiation reading by the pyronometer, "HFext" and "HFint" are the heat flow densities readings by the flux meters that were installed on the external surface.

The first day sticks out because of no parallels between solar radiation intensity and external surface heat flow density change. The result of that can be the influence of high-speed wind at the time of measuring the experiment data.

\section{Comparison of the results and theoretical calcula- tions}

The theoretical calculations were carried out using the method presented in Chapter 2.

Inside air temperature is calculated by the Eq 13.

$$
\begin{aligned}
& \theta_{i-\text { calculated }}(\Delta t)=\frac{E_{s t 1}+\Delta E_{s t 1}}{C_{1}}+\theta_{e}= \\
& =\frac{C_{1} \cdot\left(\theta_{i}-\theta_{e}\right)+H F_{\mathrm{int}} \cdot A \cdot \Delta t}{C_{1}}+\theta_{e} .
\end{aligned}
$$

where $\theta_{e}=T$-ext (measured), $\theta_{i}=T$-in $t$ (measured at the start point) $\left({ }^{\circ} \mathrm{C}\right) ; H F_{\text {int }}-$ measured heat flow density on the inside surface $\left(\mathrm{W} / \mathrm{m}^{2}\right) ; A-$ area of inside surface $=$ $8,1 \mathrm{~m}^{2} ; C_{1}$ - heat capacity of internal air $(\mathrm{J} / \mathrm{K})$ : $C_{1}=V \cdot \rho \cdot c \quad(\mathrm{~J} / \mathrm{K})$, here $V-$ inside room (inside air) volume $=44 \mathrm{~m}^{3}, \rho-$ air density $=1,15 \mathrm{~kg} / \mathrm{m}^{3}$ and $c-$ air specific heat $=1 \mathrm{~kJ} / \mathrm{kg} \times \mathrm{K} . C_{1}=50420 \mathrm{~J} / \mathrm{K}$. Time step $\Delta t$ equals data fixing step $10 \mathrm{~min}(600 \mathrm{~s})$.

Original analysis, ie without any assumptions, has shown a big discrepancy between experimental and calculations results.

If to take that the method of analysis and the primary data are correct, and air density and specific heat dependence on temperature change is insignificant, the main reason of discrepancy can be the influence of two (three) dimensional temperature and heat flow fields in the test component, ie wall. The assumption is that the measured heat flow density, measured at the central part of the wall, is not the same by the whole surface area and it is likely the most intensive heat flow appears exactly on the measured part.

Standing in this position, the measured heat flow density $H F_{\text {int }}$ cannot be attributed to the whole surface area $A$ of the wall. The additional calculations using a new value called "conditional heat exchange area" $A$ * $\left(\mathrm{m}^{2}\right)$ was carried out.

Results of the analysis with "conditional heat exchange area" $A^{*}$ are presented below (Fig 6).

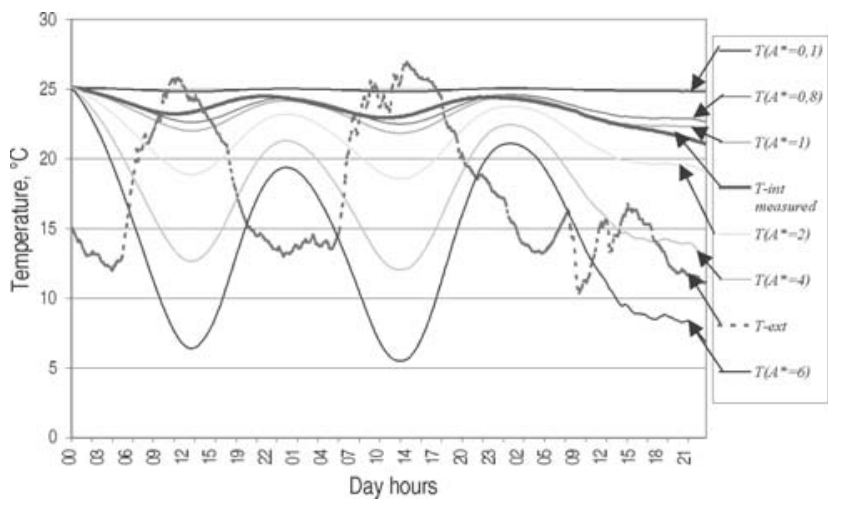

Fig 6. Comparison of the experimental results and theoretical calculations using the "conditional heat exchange area" $A^{*}$

The results of analysis show that the conditional heat exchange area $A^{*}$ is much less than the real inside surface area $A$ of the investigated wall. It means that an assumption of a more intensive heat flow density on the investigated (central) part of test component was made correct.

The best correlation of the analysis results is evident when the conditional heat exchange area $A^{*}$ is near $1 \mathrm{~m}^{2}$.

Also a lag of the calculated inside air temperature curve from the measured temperature curve appears. The most important cause of the curves lag would be the influence of the admittance of inside room boundaries. For further experimental investigations of this kind of processes the temperature of all inside surfaces must be taken into account. Another factor of the lag can be the air density and specific heat dependence on temperature change. And to get the most exact correlation of the results the functional dependence of the values mentioned above must be taken into account, too.

\section{Conclusions}

1. The presented method of unsteady heat transfer analysis in buildings is based on the energy conservation law for a control volume using the effective heat capacity of the building concept. This method allows to investigate temperature and thermal energy change at every time period. 
2. The main remarks of the experimental investigation results analysis are two times per days heat flow changing its direction because of solar radiation impact and the difference between outside air and inside curves peaks is about 10 hours.

3. The experimental investigation and theoretical calculations original analysis, ie without any assumptions, showed a big discrepancy between experimental and calculation results. The assumption that the measured heat flow density, measured at the wall central part, is not the same by the whole surface area and it is likely the most intensive heat flow appears exactly on the measured part was made. The additional calculations using a new value called "conditional heat exchange area" $A^{*}$ $\left(\mathrm{m}^{2}\right)$ was carried out and the best correlation of the results of analysis was evident, when the conditional heat exchange area $A^{*}$ was $0,8 \mathrm{~m}^{2}$.

4. The cause of other discrepancies would be the influence of the admittance of inside room boundaries, air density and specific heat functional dependence on temperature change.

\section{References}

1. Valančius, K.; Skrinska, A. An intermitted heating influence on the building reheating time and design heat load. In: Advances In Heat Transfer Engineering. Begel House, Inc., New York, 2003, p. 277-282.
2. Bogoslovsky, V. N. Building thermal physics (Строительная теплофизика). Moscow, 1982, p. 416 (in Russian).

3. Juodvalkis, J.; Blaževičius, E.; Vipartas, R. A. Analysis of an unsteady heat exchange balance in buildings. Statyba (now known as "Journal of Civil Engineering and Management"), Vol 4, No 1, 2000, p. 32-38 (in Lithuanian).

4. prEN ISO 13790. Thermal performance of buildings Calculation of energy use for space heating. Sweden: 2002, p. 10-31.

5. Valančius, K.; Paulauskaite, S. Energy conservation law appliance for intermittent heating analysis. In: Proc of 6th Intern conference "Energy for buildings". Vilnius: Technika, 2004, p. 540-547.

6. Incropera, F. P.; DeWitt, D. P. Introduction to heat transfer, 3rd ed, Wiley, New York, 1996, p. 12-41.

7. EN 832. Thermal performance of buildings - Calculation of energy use for space heating. Brussels. Belgium, 1998, p. 33-39.

8. Akander, J. The ORC method - effective modelling of thermal performance of multilayer building components. Doctoral dissertation. Stockholm, 2000, p. 24-34.

9. Valančius, K.; Skrinska, A. Transient heat conduction process in the multilayer wall under the influence of solar radiation. In: Improving human potential program. Proc, 2002. Almeria, Spain: PSA, p. 179-185.

10. Plataforma Solar de Almería. Annual technical report, 1998, p. 2.1-2.9.

\section{NESTACIONARIŲJU ŠILUMOS MAINU PROCESU PASTATE TYRIMAS}

\section{K. Valančius, A. K. Skrinska, S. Paulauskaitė}

Santrauka

Praktikoje beveik visi energetiniai procesai pastatuose yra nestacionarieji, t. y. kintantieji laike. Tuo tarpu energijos poreikiai, temperatūros pokyčiai dažniausiai vertinami neatsižvelgiant i nestacionariujų veiksnių poveiki. Dėl to, kaip rodo praktiniai stebejjimai ir teoriniai tyrimai, dažnai, net ir esant pažangiam mikroklimato sistemų valdymui, atsiranda patalpų vidaus šiluminio režimo nepageidaujamų pokyčių, neigiamai veikiančių patalpų šilumini komfortą, iškreipiančių realuji pastato energijos suvartojimą. Todèl iškyla būtinybė ieškoti kitų problemos sprendimo metodų bei tyrimų.

Straipsnyje pristatomi kai kurie teoriniai nestacionariujų šilumos mainų analizès, paremtos energijos tvermès dèsnio pritaikymu, aspektai. Taip pat pateikiami Ispanijos saulès energijos tyrimų centre Plataforma Solar de Almeria natūraliomis sąlygomis atlikto eksperimentinio tyrimo rezultatai, kurie palyginami su teoriniais skaičiavimais.

Raktažodžiai: nestacionarieji šilumos mainai, pastato šilumos režimas, eksperimentinis tyrimas.

Kęstutis VALANČIUS. MSc, Assistant at Heating and Ventilation Dept, Vilnius Gediminas Technical University. Research interests: unsteady heat transfer processes, temperature fields in building structures.

Alfonsas Kazys SKRINSKA. Prof at Heating and Ventilation Dept, Vilnius Gediminas Technical University. Research interests: renewable energy, heat and mass transfer.

Sabina PAULAUSKAITĖ. Doctor, Assoc Prof at Heating and Ventilation Dept, Vilnius Gediminas Technical University. Research interests: building thermal and moisture physics, heat and mass transfer. 